\title{
FACTORS AFFECTING CHANGES IN PERCEPTIONS OF TURKISH PEOPLE TOWARDS SYRIAN REFUGEES
}

\author{
MUCAHIT NAVRUZ, MEHMET AKIF CUKURCAYIR
}

\begin{abstract}
:
Until recently, Turkey known as a source or transit country in migration routes, transformed into a target country for refugees due to civil wars and foreign interventions in countries of the region. Refugee influxes caused by the civil war in Syria has made Turkey one of the countries with the highest refugee population in the world. With the start of the civil war in Syria, Turkey applied 'open door policy' and temporary protection was granted to all Syrians on prima facie basis.
\end{abstract}

Although the adoption of the psychological threshold of 100 thousand refugees at the initial period of the crisis, threshold was exceeded in a very short time and assumptions of Turkish government about civil war have not realized. Furthermore Al-Asad regime has strengthened its position because of the disharmony and inconsistency in opposition groups. With the interval of radical islamic groups, parallel with the decline in public support in Western countries, Syrian policy of Westren governments began to change. Active support to opposition declined and civil war turned into a vicious cycle. The most significant effect of this situation on Turkey is transformation of short-term guests into permanent refugees. Prolongation of the civil war reducing the Syrian's prospects of return, made Turkey host one of the most populous diasporas in the world.

With increasing economic and social burdens, Turkey's 'human-rights based approach' to Syrian refugee policy bagan to show signs of exhaustion and 'security based approach' came up to the agenda. Main factor causing this condition is perception changes of Turkish people against Syrian refugees. In this paper, factors affecting the perception of the Turkish people will be examined.

\section{Keywords:}

Refugees of Syrian Civil War, Urban Refugees, Host-Refugee Relations

JEL Classification: F22

\section{Authors:}

MUCAHIT NAVRUZ, Selcuk University, Turkey, Email: mucahitnavruz@selcuk.edu.tr MEHMET AKIF CUKURCAYIR, Selcuk University, Turkey, Email: akifcukurcayir@gmail.com

\section{Citation:}

MUCAHIT NAVRUZ, MEHMET AKIF CUKURCAYIR (2015). Factors Affecting Changes in Perceptions of Turkish People Towards Syrian Refugees . International Journal of Social Sciences, Vol. IV(4), pp. 75-85., 10.20472/SS.2015.4.4.006 


\section{Introduction}

Globalization is a process that dissolve the concrete boundaries between countries and decrease the quantitative distances, at the same time, build intangible boundaries and increase the qualitative distantances. Since 19'th century, occurence of state sovereignty on the basis of ethnic or cultural unities and clearer borders between nation states, distinction between citizens and foreigners became visible and modern international migrations started. Border clashes and civil wars stem from artifical boundaries drawn between states that gained independence in post-imperialist period has led to globalization of migration movements. (Zolberg et al , 1992: 37-72)

Middle East is the region has seen recently and frequently refugee movements as part of international migrations. Afgan refugees after Soviet war in Afghanistan, Afghan civil war and War in Afghanistan lead by U.S, Iraqi refugees after Iraq War, Sudanese refugees after ethnic civil wars in Sudan and refugees after civil wars in Libya and Syria triggered by Arab Spring flooed to the other countries in the region.

Protest movements in Syria as an extension of broader Arab Spring was tried to suppress by regime forces with violent methods and political activists that took active roles in protests fled the country primarily (Ozden, 2013:4). With the increased oppresssion by regime and turning peaceful protests of the opposition into armed action, civil war spread throughout the country in a short time. As a result, profile of refugees changed and millions of refugees passed the borders of neighboring countries.

Defined as the "worst humanitarian disaster since the end of the cold war," the Syrian civil war has to date claimed over 200,000 casualties. In a country of approximately 22 million people, the bloody and prolonged conflict has resulted in more than 10 million Syrians, or $45 \%$ of the country's population are believed to have been forced out of their homes due to the conflict. Of those, 6.5 million are displaced within Syria and approximately 4 million people have sought refuge in other countries. Of this 4 million, 3.8 million - or 95\% - are now in just five host countries: Turkey, Lebanon, Jordan, Iraq and Egypt, as well as approximately 12.2 million people (more than 1 in 2 Syrians) in need of humanitarian aid to survive (Amnesty International, 2014: 2). By mid-2014, at more than three million registered refugees, Syrians had overtaken Afghans as the largest refugee population under UNHCR's mandate, a reflection of the continuous conflict and violence in the country (UNHCR, 2014: 5).

Turkey as a natural result of $877 \mathrm{~km}$ land border and socio-cultural relations with Syria became one of the main destinations for refugees escaped from civil war. As of January 1, 2015 according to the figures by UNCR, total Syrian people of concern in Turkey 1,6 milion and this number does'nt contain undocumented refugees (Syria Regional Refugee Response, 2015). With this figures, Turkey has the sixth-largest 
refugee population in the world and has become the fourth largest donor country. UNHCR statistics also show 170 thousand refugee candidates in Turkey from other countries except from Syrians waiting for resettlement process for third countires (Erdogan, 2014: 16). Although this is extremely high number for a country, there was no significant affect in local public perceptions because of invisibilitiy of these refugees. It is seen obviously that local perceptions affected by Syrian influxes that more visible and perceivable.

Voluntary repatriation is seems to be impossibble in the near future and resettelement oppurtunities are very limited, so local integration of refugees remained only possible solution for Turkish state. But path to the succesfull integration passes from hostrefugee relations. Atmosphere of relative hospitality at the initial period of civil war began to replace with discriminatory discourses especially in provinces close to the region and individual hate discourse started to become organized and constant mass demonstrations against Syrians occured.

\section{Syrian Urban Refugees in Turkey and Factors Affecting Local People-Refugee Relations}

At first glance, the concept of refugee brings to the mind a fenced rural camp consisting tents and families live in norrow circles. But as a result of changing demographic phenomenon, settlement practices deeply affected and new order showed its impacts on refugee settlements (Landau, 2004: 4) Urbanization process gave birth to the 'urbanization of refugees' also. Transformation of refugee migration patterns find urban areas as an alternative against refugee camps and rural settlements.

Although urban refugees are not legally defined in national legislations, way of lives and common characteristics of a group can be enough to conceptualization of urban refugee. Based on similar characteristics all over the world, urban refugees can be defined as refugees preffered or obliged to settle in urban areas in the country of asylum instead of refugee camps. Urban refugees live in designed special settlements for them or randomly determined settlements by themselves.

According to recent datas, $58 \%$ of refugees worldwide are known to live in urban areas. (http://urban-refugees.org/). Although there is no reason to anticipate a reduction in numbers of urban refugees in the near future, increases are expected in urban refugee numbers and rates, because of ongoing conflicts and urban refugee policies of nation states (Landau, 2004: 3). High urbanization rates in underdeveloped and developing countries are also increasing expectations.

Refugees in urban areas can be classified as a subset of the two larger population groups; other-foreign born migrants and urban poors. Because urban refugees live amongst them, share the very same challenges (Jacobsen, 2006: 276) Although refugees and other urban poors may be exposed to similar problems, urban refugees 
experience additional problems such as legal status issues and is faced with xenophobic attitudes of local hosts (Jacobsen, 2004: 57).

Hesitant and reluctant behavior of the nation-states to refugee integration practices and inadequate assistance from local and international organizations, forced urban refugees to integrate into livelihoods by informal means with their own economic and cultural contributions. In this regard, from the moment they took refugee in host country, refugees enter into competiton with the locals over limited resouces like water, food, shelter, work and services such as education and health. The process of de-facto integration in this way causes direct impacts on local people's perception of refugees. Socio-economic relations of refugees with host population have significant effects on quality of life and integration of refugees (Porter et al, 2008: 232). In the context of this relationship, refugees either integrate into the urban areas and maintain a sustainable life or continue their life in ghetto type formations that isolated from urban areas (Sommers, 2001: 353).

Acording to Jacobsen, sustainable life of refugees can only achieved by integration of refugees into local communities. In order for the realization of integration, refugees should be reassured that they are secured from physical hazards, should not live in danger of deportation and have the ability to return to their country whenever they want. Primary requirement to actualize these elemets is a health relationship between local communities and refugee communities (Jacobsen, 2001: 9).

Perception of host communities are diversified acording to unilaterally reasons developed by locals such as historical prejudices or common historical heritage, ethnic and sectarian differences or similarities, communication difficulties, differences in lifestyles and bilaterally reasons that directly or indirectly arising from the environmental impact of refugees. Turkish perception of Syrian refugees can be traced in all these factors. But current persecption toward Syrian refigees stem from 3 main factors. Demographic/Ethnic transformation in the region, secterian factors trigger susupicion towards refugees and perceived aconomic burden to local people.

\section{- Demographic-Ethnic Factors}

Ethnicity of refugees has direct impacts on relationsips with host governments and local people. Common religions and religios sects, languages, color and ethnicitieas are important factors in this respect. Acording to Campbell, each group of refugees are perceived differently by the local people and develop relationships with different levels in Nairobi (Campbell, 2006: 406-407). Similarly, dark-skinned african refugees in Cairo were subjected to particular ethnic discrimination by the Egyptian people, but refugees from other African countires such as Sudan which have common ethnicity are not are exposed to racist and xenophobic acts by local people (Grabska, 2006: 297). Distinctions of race and color makes more impact on local people's perceptions than 
shared religious values (Erdogan, 2014: 25). A similar case for Sudan supports this phenomenon that Eritran refugees that have common etniticty and religions with Sudanese, are able to reside in the cities, can be employed in labor market, even acquiring the property, despite strict encampment policies of Sudanese governmet. However, this is not the case for refugees from ethnically or religiouslydifferent countires such as Somali and Kenya (Fabos and Kibreab, 2007: 4).

This condition is also possible to be find in Syrian refugees case. The ethnicity of the refugees create differentiation in the perception of different ethnic or sectarian groups in Turkey. Parceptions of Arabs to Kurds, Arabs to Arabs, Alevis to Sunni Arabs, Turks to Turkomans and Kurds to Kurds differ highly depending on ethnic origins (Erdoğan, 2014: 19-20). Turkish people in the border regions form their approach towards Syrians in accordance with their own ethnic, religious and political identities. For example, there is sympathy towards Kurds and antipathy against Arabs in the places that Kurds form the majority. Kurds think that Arabs support radical groups such as alQaeda, which they use against the Kurds in Syria. In contrast, Arabs think that Kurds seek to divide Syria and support PKK-affiliated parties. The majority of Turks sympathize with Turkmens, while most of the Arab Alawites consider the Syrians entering Turkey as traitors to their own country (ORSAM, 2014: 17).

Latest population cencus that envisages ethnic-based information in Turkey was carried out in 1960 in Turkey. According to this census 34\% of Hatay, $21 \%$ of Mardin, $13 \%$ of Urfa, Gaziantep and \%1 of Kilis is described Arabic as mother language. Also $\% 1,17$ of total population in Turkey idendified Arabic as mother languages (DIE, 1963). A current research by KONDA in 2007 supports these findings that 1,38\% of Turkey defined Arabic as the native language (http://www.milliyet.com.tr/2007/03/22/guncel/agun.html) If calculated high birth rates in Southeast where the density of Arab ethnicity live, these datas support each other.

Vast majority of Syrian refugees are ethnic arabs and this situation is a major transformative element in demographic/ethnic distribution in regional provinces. After refugee influxes etnnic balance changed in favor of Arabs. Increases in Mardin from $21 \%$ to $25 \%$, in Urfa from $13 \%$ to $19 \%$ and in Kilis from $\% 1 \%$ to $\% 42$ reflects the sizes of transformation (Cagaptay, 2013: 2). Hatay, most heterogeneous province in Turkey is the most affected case. Ethnic Arab population rised in Hatay from \%34 to $\% 40$. Unregistered refugees because of geographic proximity with Syria and continuous enterances and exits within borders causes estimates to be more. So Hatay can be assesed as the first province has etnic Arab majority (Cagaptay, 2013: 13). Beside these provinces, districts located next to the Syrian border in the region suh as Suruç, Akçakale and Reyhanli are places that demographic structure significantly transformed. 
For the prevention of ethnic disturbances, new refugees are redirected by government from ethnically sensitive provinces and districts to interior regions. Refugee quotas for each provinces and districts will also provide important contributions to the process of integration and burden sharing among regions.

\section{- Secterian Factors}

Refugee movements often used as a tool to redesign secterian boundaries in a society. For example, in Shiite dominated Bahrain, Sunni administration is constantly criticized by giving 5 thousands sunni refugees citizenship in order to turn balance in favor of Sunni minority (http://www.bahrainobserver.com/en/page/114/Bahrain++Naturalise+5000+Syrians+ Refugees+.html )

In connection with demographic and ethnic pressures, secretian factors also very important in some spesific areas in Turkey such as Hatay province. As mentioned above Hatay has a very heterogeneus population that majority of Arab population in province is Alawite sect and Sunni and Christian Arabs form a minority. So that local Alawites are very suspicious abut refugees and see the influxes as an intentional demographic engineering (Cagaptay, 2013: 14). Although there are significant differences between the Alewites in Syria and Turkey, teo sects have similar secularist reactions and suspicion against Sunnis. Pro-Assad demonstration organized by Platform Against İmperialist Intervemtion in Syria and other rallies against Syrian refugees reflected this perception.

Another example of secterian perceptions, after siege of Kobane by ISIL militants hundreds of thousands of Syrian Kurds crossed the border and settled in South East of Turkey. Conflicts between radical İslamists and Syrian kurds also made impact in Tukey. Pro-İslamists and Pro-Kurd fractions came confronted in many cases.

\section{- Ecomomic Factors}

The basic elements of refugee perception issues is given to the economic success of the refugees. Economic situation of refugees and the local population can exert pressure or relief on limited economic resources and opportunities in urban areas. (Jacobsen, 2004: 63). Considering the economic impact of Syrian refugees, camp refugees and urban refugees raises different results.

The presence of refugees in camps makes an economic burden for the state. More than 200 housand refugees live in 22 refugee camps stationed in 10 provinces in Turkey (AFAD, 2013:12-13). The physical conditions in the camps, frequently praised by international institutions from other countries in the world but Turkish authorities wait burden sharing in exchange for protection and services offered in the camps more than 
praises Until August 2014, financial expenditures fo Turkey's on Syrian refugees exceeded 4.5 billion US dollars, also 635 million dollars support has provided by the Turkish NGOs. Foreign aid to Turkey within this period is 233 million dollars, in total expenditure of just\% remained at 4.1. (Kirişçi and Salooja, 2014). Limited possibilities of interaction with the local population in the refugee camps is not correct for urban refugees. Isolated structure of refugee camps limits refugee-host interactions and economic burden of camp refugees is not perceived by local people directly. Compared to their nationals living in refugee camps, urban refugees are usually active in the economic structure of the city so the economic impact of urban refugees is directly linked with the local population..

Even though the economic impact of urban refugees relatively less than camp refugees and in some cases, in the positive direction, visibility and direct effect of urban refugees on socio-economic environment perceived by local people directly. According to the estimates of the United Nations High Commissioner for Refugees (UNHCR), the majority of the world's refugees now reside in cities or towns. In contrast to camps, where refugees are relatively isolated from local host communities and more dependent on assistance from humanitarian agencies to meet their basic needs, refugees in urban areas typically depend more on social networks, relationships and individual agency to re-establish their livelihood (CWS, 2013).

Refugees' economic success and failure makes impact at different rates in different segments of society (Chambers, 1986). In cases where the refugees are more succesfull than local population, discrimination widely experienced (Alexander, 2008: 37). In the case of Turkish guest-workers/gastarbeiters in Europe, migrants that initially accepted as temporary, became permanent and economically became stronger. Describing this process the Swiss writer Max Frisch "We called for workers but human beings came ' has summarized the situation. Over 80 percent of the refugee population is concentrated chiefly outside of camps in five provinces in the south and southeastern Turkey, thus representing a substantial presence and having a significant impact on each of these areas (Berti, 2015: 42).

Main problem for economical perception is burden sharing among economic groups and regions. Spatial choices of Syrians varies according to their economic situation in Turkey. High income groups took all movable properties with themselves and refuged to metroplitan cities in Turkey in the first phase of civil war. Middle income groups has chosen to settle in the nearby towns of the boundary. Low-income groups have benn settled in camps in the region or were forced to reside IDP camps established inside Syria (Ozden, 2013: 4). So impact of refugees perceived by low and middle income grops of local people directlly and negatively, but this is not the case for high income groups and sectors profit from refugees. 
Employment in informel sector is the most popular choice for refugees beacuse of the low start-up capital, exemption from taxes and differentiation opportunities for target groups. This condition causes antogonismin local people dealing with similar business and small business owners Status of Syrian refugees are not not legally compliant so refugees are tend to work informal sectors or turned into cheap labor. Most refugees are working in textile, construction, agriculuture and heavy industries (Kirişci and Salooja, 2014). Daily wages in the region decreased from 60 to 20 Turkish Liras. Rising prices and rent increases as much as \%100 affect negativeley lower income groups and fixed-income citizens (Kilis Common Sense Community, 2013).

Besides all this negative factors, Syrians have provided a considerable amount of economic contribution. In 2013 number of combanies established by Syrians increased threefold. Some Syrian businessmen have moved their factories to Turkey and there has been a huge amount of capital inflows (ORSAM, 2014: 16) According to 2013 data from Turkish Statistical Institute (TSI) Gaziantep is the first provinces that incriasing capacity and simultaneously decreasing employment rates. This amazing numbers shows us the new economy created by refugees from Syria (Erdogan, 2014: 16). Despite the dramatic proportions of the refugee crisis in southeastern Turkey in 2012 and 2013, its impact on local commodity and labor markets do not seem to be considerable. Perhaps the only disconcerting finding from the natives' perspective is the ination of food and (to a lesser extent) housing prices (Akgündüz et al, 2015: 18)

\section{Conclusion}

Increased oppresssion by regime and turning peaceful protests of the opposition into armed action, civil war spread throughout Syria in a short time. As a result, millions of refugees passed the borders of neighboring countries. Inevitably, Turkey became one of the main destinations for refugees escaped from civil war Voluntary repatriation to Syria is seems to be impossibble in the near future and resettelement oppurtunities to third countires are very limited, so local integration of refugees in Turkey remained only possible solution for Turkish state. But there is a major obstacle for succesfull integration: Growing discontent of local people.

As seen in almost all the countries that affected by foreign migrations. Perception of Turkish people also evolved from 'hospitality' to exhaustion. Perception of host communities are diversified acording to unilaterally reasons developed by locals such as historical prejudices or common historical heritage, ethnic and sectarian differences or similarities, communication difficulties, differences in lifestyles and bilaterally reasons that directly or indirectly arising from the environmental impact of refugees. Turkish perception of Syrian refugees can be traced in all these factors. But current persecption toward Syrian refigees stem from 3 main factors. Demographic/Ethnic transformation in the region, secterian factors trigger susupicion towards refugees and perceived economic burden to local people. 
If there will be no progress in factors affecting refugee perceptions of local people in a positive direction, refugees that suffers lots of problems already, presumably will experience major psychosocial problems in maintaining their lives.

\section{Resources}

AFAD (2013). Syrian Refugees in Turkey, 2013 Field Survey Results, Turkish Disaster and Emergency Management Presidency.

Akgündüz, Y., Van den Berg, M., \& Hassink, W. H. (2015). The Impact of Refugee Crises on Host Labor Markets. The Case of the Syrian Refugee Crisis in Turkey.

Amnesty International (2014). Left out in the cold; Syrian refugees abandoned by the international community.

Cagaptay, S. (2013). The Impact of Syria's Refugees on Southern Turkey. Washington Institute for Near East Policy, 1.

Campbell, E. H. (2006). Urban refugees in Nairobi, Problems of protection, mechanisms of survival, and possibilities for integration. Journal of refugee studies, 19(3), 396-413.

TSI (1963). General Population Cencus 1960, Turkish Statistical Institute Publishing .No:444, Ankara.

Erdoğan, M. (2014). Syrians in Turkey, Social Acceptence and Integration Research, HUGO http://www.hugo.hacettepe.edu.tr/HUGO-REPORT-SyriansinTurkey.pdf

Fábos, A., \& Kibreab, G. (2007). Urban Refugees; Introduction. Refuge; Canada's Periodical on Refugees, 24(1), 1-19.

Grabska, K. (2006). Marginalization in urban spaces of the global south, Urban refugees in Cairo. Journal of Refugee Studies, 19(3), 287-307.

Jacobsen, K. (2001). The forgotten solution, local integration for refugees in developing countries. United nations High commissioner for refugees (UNHCR).

Jacobsen, K. (2004). Just enough for the city; Urban refugees make their own way. World Refugee Survey, 2004, 57-67.

Jacobsen, K. (2006). Refugees and asylum seekers in urban areas a livelihoods perspective. Journal of Refugee Studies, 19(3), 273-286.

Kirişçi, K and Saloja (2014). Northern Exodus, How Turkey Integrate Syrian Refugees, Foraign Affaris.

Landau, L. (2004). FMO research guide, urban refugees. Forced Migration Online 
Porter, G., Hampshire, K., Kyei, P., Adjaloo, M., Rapoo, G., \& Kilpatrick, K. (2008). Linkages between livelihood opportunities and refugee-host relations learning from the experiences of Liberian camp-based refugees in Ghana. Journ

ORSAM (2014). The sitıation of Syrian Refugees in neighbouring countries.

Ozden, S. (2013). Syrian Refugees in Turkey, MPC Research Report 2013-05

Sommers, M. (2001). Young, male and Pentecostal; urban refugees in Dar es Salaam, Tanzania. Journal of Refugee Studies, 14(4), 347-370.

Syrian Refugee Response (2015) http://data.unhcr.org/syrianrefugees/regional.php

UNHCR (2014) Mid Year trends. http://unhcr.org/54aa91d89.html

Zolberg, A. R., Suhrke, A., \& Aguayo, S. (1992). Escape from violence, Conflict and the refugee crisis in the developing world. Oxford University Press. 